\title{
SOBRE O USO DA MISÉRIA HISTORIOGRÁFICA E A RELEVÂNCIA DA INVESTIGAÇÃO HISTÓRICA NA APLICAÇÃO DO DIREITO DO TRABALHO
}

\author{
ABOUT THE USES OF THE HISTORIOGRAPHIC MISERY AND THE RELEVAN- \\ CE OF HISTORICAL RESEARCH IN THE APPLICATION OF LABOR LAW
}

Gustavo Seferian $^{1}$

\begin{abstract}
Resumo: O presente artigo discute a importância da história do Direito do Trabalho para a aplicação de suas normas pelo Poder Judiciário. Pretende, ao evidenciar ( $i$ ) a carência de estudos historiográficos juslaborais, (ii) a mistificação dos processos históricos que levaram à formação do Direito do Trabalho no país, sobretudo (iii) pela formação da narrativa oficial da outorga de direitos e (iv) ao se imputar a alcunha de "fascista" à legislação laboral, colaborar com a discussão teórico-crítica acerca da historiografia da matéria, com vistas a promover uma leitura de totalidade acerca da atual conjuntura e do papel da Justiça do Trabalho no fomento da proteção jurídica das trabalhadoras e trabalhadores, fortalecendo seu telos original e contraditório. Para tanto, nos utilizamos do método materialista dialético na formulação de elaborações de caráter teórico, tomando por base textos de fundo historiográficos, sociológicos e filosóficos.
\end{abstract}

Palavras-chave: História do direito do trabalho; Historiografia crítica; Justiça do Trabalho; Fascismo.

\begin{abstract}
This article discusses the importance of the history of Labor Law for the application of its norms by the Judiciary. It seeks to highlight (i) the lack of historiographical studies on labor law, (ii) the mystification of the historical processes that led to the formation of Labor Law in Brazil, especially (iii) by the formation of the official narrative of the granting of labor rights and (iv) by imputing the "fascist" reputation to the Labor Legislation, collaborating with the theoretical-critical discussion about the historiography of the subject, aiming a totalizing reading about the current conjuncture and the role of the Labor Courts in the promotion of the legal protection of workers, strengthening their original and contradictory purposes.For this purpose, we use the dialecticcal materialista method in the formulation of theoretical elaborations, based on historiographical, sociological and philosophical background texts.
\end{abstract}

Keywords: History of Labor Law; Critical historiography; Labor courts; Fascism.

"Vous!... de prendre mon moulin?

Oui, si nous n'avions pas des juges à Berlin."

- François Andrieux (1800, p. 47), Le Meunier Sans-Souci

\footnotetext{
1 Professor Adjunto, em regime de dedicação exclusiva, do Departamento de Direito do Trabalho e Introdução ao Estudo do Direito da Universidade Federal de Minas Gerais (DIT-UFMG). Professor do corpo permanente do Programa de PósGraduação em Direito da Universidade Federal de Minas Gerais. Doutor em Direito do Trabalho pela FDUSP (2017), orientado por Jorge Luiz Souto Maior, sendo a tese aprovada com louvor e distinção. Titulou-se na mesma instituição mestre em Direito do Trabalho (2012, aprovado com louvor) e bacharel em Direito (2008).Pesquisador convidado, em sede de pós-doutorado, do CéSor/EHESS/CNRS, sob supervisão de Michael Löwy (2018). Foi Professor Adjunto de Direito da Universidade Federal de Lavras - UFLA (2016-2019) e de outras instituições de ensino superior. Desenvolve pesquisas em Teoria do Direito do Trabalho, História do Direito do Trabalho, Relações Sindicais, Processo Trabalhista e Direitos Sociais, pautado pela leitura marxiana, na tradição marxista e no ecossocialismo. E-mail: seferian@ufmg.br
} 


\section{BREVES APONTAMENTOS INTRODUTÓRIOS}

O presente artigo pretende trazer reflexões acerca da importância da compreensão histórica do Direito do Trabalho no processo de sua aplicação, com foco na conformação dada ao referido campo jurídico pelo Poder Judiciário. Intenta assim colaborar com a discussão teórico-crítica acerca da historiografia juslaboral, com vistas a promover uma leitura de totalidade acerca da atual conjuntura e do papel da Justiça do Trabalho no fomento da proteção jurídica das trabalhadoras e trabalhadores, isso com vistas de que a regulamentação das relações de assalariamento cumpra seu telos original e contraditório.

Para tanto, seguindo a chave reflexiva de uma expressão popular entre juristas - "ainda há juízes em Berlin" -, pretendemos ( $i$ ) traçar um panorama conjuntural de fundo, expondo como a crise do capital impacta na práxis judicante; (ii) expor, em breves linhas, como a história do Direito do Trabalho sempre foi uma temática relegada ao segundo plano pelos teóricos juslaboralistas - atuando na práxis forense ou nos bancos universitários -, que acabam por ecoar, ao menos em regra, a narrativa oficial da conformação da legislação laboral no país, tudo visando apontar o quanto este vazio teórico é funcional à mistificação do papel social da regulamentação jurídica do trabalho e seu consequente desmonte; (iii) incidir criticamente sobre uma das recentes - em que pese também já bastante ancestrais - discussões sobre as origens do Direito do Trabalho brasileiro, qual seja, a que reputa ser o referido ramo de caráter fascista; (iv) tudo para denotar a disfunção social que o desmonte da Legislação do Trabalho pode vir a ensejar tanto a trabalhadoras e trabalhadores, quanto a capitalistas.

Optamos, para tanto, pela apreensão de nosso objeto crítico desde o método materialista dialético, pelo que buscaremos formular elaborações de caráter teórico tomando por base textos de fundo historiográficos, sociológicos e filosóficos.

Eis a síntese de nossas reflexões.

\section{CRISE CIVILIZACIONAL COMO CENÁRIO DA OFENSIVA CONTRA O DIREITO E JUSTIÇA DO TRABALHO}

Há uma expressão de uso corrente entre aquelas e aqueles que depositam suas crenças fortes no direito e no Judiciário, sobretudo como instrumentos de consagração da justiça e interdição de toda forma de imposição e arbítrio, que diz que, contra tais males, há de se ter esperança pois "ainda há juízes em Berlin”. A variação desesperançosa do dito por vezes também aparece, nas queixas de que não mais existem magistrados na capital alemã.

Indiferentemente do tom que manifesta, é certo que a expressão remete ao conto de François Andrieux intitulado "Le Meunier Sans-Souci", originalmente publicado em 1800. A anedota gira em torno da discussão entre um moleiro e Frederico II, dito "o Grande", acerca de um moinho. Sendo de propriedade do primeiro, e desejado pelo segundo - haja vista que a aquisição da azenha viabilizaria expandir seu castelo -, foi objeto de proposta de compra pelo monarca. O moleiro, porém, recusou o lance, seguindo irredutível do começo ao fim das negociações, muito amparado em questões pessoais, haja vista que naquele moinho vivera seu pai, e também almejava que vivessem 
seus filhos. Ante a renitência do moleiro, o monarca, em arroubo arbitrário - já que mesmo esclarecido, não tinha perdido a coroa -, lança ameaça e diz que, dada a sua condição, poderia mesmo tomar a propriedade do pobre trabalhador, sem necessidade de pagar. Diante de tal disparate, e sem transparecer hesitação, é que responde o moleiro com a frase que nos serve de epígrafe: “"Você!... tomar meu moinho? Sim, se nós não tivéssemos juízes em Berlin"”. É o suficiente para o esclarecido rei recuar de seus anseios, e reconhecer que ante a sua autoridade pretensamente absoluta, erige-se outra mais forte, que apenas pela tradição tinha ousado se colocar contra.

É inegável que Andrieux - jurista, entusiasta da Revolução burguesa na França, membro da Académie françeise e magistrado durante os anos que seguiram o Terror - transparece sua crença não só nas Luzes, como também em um novo arranjo social e político que passa a se erigir sob seus olhos e por suas forças. A afirmação hegemônica do capitalismo na Europa, até então só econômica, passa doravante também a ser política. Nesse quadrante, como lembra Sérgio Resende de Barros (2008) - bastante impactado pelas leituras de Carré de Malberg -, a lei toma lugar do rei, e o magistrado, enquanto "boca" da nouvelle ordre, passa a assumir vulto político na sua consolidação.

Esta crença, vale dizer, não se resume ao autor que nos serve de indutor reflexivo. Ela mantém-se, enquanto ideologia dominante da ordem produtiva capitalista, prevalente no ocidente desde então, com modulações diversas desde as realidades centrais e suas manifestações dependentes e periféricas - como a nossa. Afinal, como Marx e Engels (2007; p. 47) não nos deixam esquecer, "as ideias da classe dominante são, em cada época, as ideias dominantes, isto é, a classe que é a força material dominante da sociedade é, ao mesmo tempo, sua força espiritual dominante", e isso indiferentemente do compasso em que se dá o desenvolvimento desigual e combinado da ordem. Do centro às margens, assim, irradiou-se a percepção inabalável de que porquanto tivermos magistrados, a justiça será feita.

Aparente, porém, era esta estabilidade. O processo de afirmação histórica da relação social do capital revelou que sua lógica de expansão não comportava linearidades expansivas e que os sobressaltos eram frequentes e indissociáveis de sua essência. A crise, enquanto negativo do capital (GRESPAN: 2012), é e sempre foi a sombra que acompanha e assola o modo de produção hoje dominante.

A expressão de confiança na magistratura chega aos nossos tempos, e à nossa realidade sócio-histórica, comportando uma série de nuances e novos sentidos. Isso pelas próprias mudanças em que a sociedade capitalista, desde então, acabou por passar em seu moto de afirmação global. Em um cenário de acentuada crise da ordem produtiva, assumindo traços de uma crise civilizacional em que se combinam elementos econômicos, ecológicos, sociais, morais, humanitários etc (LÖWY: 2013), aqueles paradigmas que, à época de Andrieux, se solidificavam agora "desmancham no ar" (MARX; ENGELS: 2010; p. 43). Também os pedidos de amparo ao Judiciário nestes tempos de interdição estrutural à reprodução do capital se veem fragilizados, haja vista que, como aponta Mandel (1977; p. 51), "uma crise em um setor" da sociedade capitalista "repercute em todos os demais setores", e o Judiciário não passa incólume aos seus efeitos. Como exemplo desses impactos, para além do esvaziamento das atribuições e sucateamento do aparelho judicante, encontram-se ataques ainda mais explícitos e politicamente impactantes. A realidade brasileira já experimentou situações gravíssimas nesse sentido, haja vista que a afirmação desesperada da 
ofensiva capitalista para salvaguarda de lucros pode flexionar até as garantias mais inquebrantáveis da magistratura. Para ficarmos em um exemplo, derivado de outro momento de crise, vejamos a ditadura empresarial-militar no país, em que até mesmo ministros do STF foram cassados - como foi o caso de Victor Nunes Leal, Hermes Lima e Evandro Lins e Silva. Como depositar a confiança frente ao arbítrio em juízes e juízas fragilizados em seu agir profissional, em sua autonomia para salvaguarda de um interesse pretensamente geral?

Os ares de hoje parecem, ao menos pelos sinais da falência sistêmica, anunciar dias bastante nebulosos. Ainda que sofrendo os efeitos da referida crise civilizacional, o Judiciário assume papel ímpar e, podemos dizer, até então nunca alcançado na história política do país, o que não revela, porém, um fortalecimento da instituição enquanto tal, senão um escapismo pela via judicante para resolução de problemas que mereceriam respostas pela grande política. A combinação de fatores - fragilização institucional e aposta nesse debilitado poder para solução de impasses políticos - é explosiva. Ou melhor, corrosiva. E se a lida com a institucionalidade e legalidade burguesas em sua compreensão mais pura e ideal já se coloca frustrada e viciada pela seletividade e cegueiras ideológicas, o que dizer do trato do Direito do Trabalho, expressão da torção política dos registros de igualdade e liberdade em que se assentam a lógica originária da juridicidade capitalista, guardião jurídico do reconhecimento da desigualdade material entre sujeitos das relações de assalariamento e da necessidade proteção de quem trabalha?

A aplicação do Direito do Trabalho pelo judiciário é por certo uma das encruzilhadas difíceis de se contornar. À legislação trabalhista projeta-se a responsabilidade pela crise, pela carência de investimentos pelo capital, pelo desemprego, e, de forma derivativa, à Justiça do Trabalho, o gravame de sua efetivação - ainda que saibamos se dar de forma assaz modulada, pouco incisiva, sobremaneira diante do império conciliatório que lhe determina a práxis e organização, marcando de forma cada vez mais acentuada este ramo do Judiciário.

Mas nada a se surpreender. O Direito do Trabalho, em si, é expressão da crise da ordem capitalista, vindo em resposta à mesma (SEFERIAN, 2017). Não é de se estranhar que, em uma outra crise civilizacional, seja este descartado, rifado, como se desfuncional. E isso por efeito do desespero capitalista na busca de soluções ao irresolúvel. Mal sabem, individualmente, que tanto o Direito do Trabalho quanto a Justiça do Trabalho, enquanto instrumento de efetivação do primeiro, são indispensáveis e de todo funcionais na contenção à determinação caótica da reprodução capitalista.

Expliquemo-nos.

A matéria juslaboral, porém, dadas as suas características aparentemente afrontosas à lógica de livre mercado e às ganas individuais do capitalista em obter o máximo da força de trabalho por si contratada, passa ordinariamente, e de fato vem também passando no corrente momento, por toda uma série de ataques, que vão desde flexibilizações legislativas, desmonte de aparelhos de fiscalização, e, mais relevantes, uma inflexão na práxis contratual, impactando em demasia a organização das relações de trabalho e resultando em intensificação de mazelas experimentadas pelas camadas mais fragilizadas das classes trabalhadoras, que não podem ser percebidas sem atenção a seus marcadores de gênero e raça, sobretudo em nossa realidade dependente e periférica. Isso por desconsiderar que, em verdade, o Direito do Trabalho, como não poderia deixar de ser, é um 
direito capitalista (JEAMMAUD et al. 1980; RAMOS FILHO: 2012), contando com contraditórios e relevantes papéis, tanto no que se refere às salvaguardas materiais de quem trabalho - logo, condicionantes da dual existência ${ }^{2}$ das classes trabalhadoras - como viabilizando, pela partilha (ainda bastante desigual) da riqueza produzida, a reprodução da relação do capital por contrarrestar a queda tendencial da taxa de lucro, "lei" anunciada por Marx, em O Capital, como uma das mais profundas contradições da ordem econômica hoje dominante. Ou seja, tais perspectivas redistributivas da riqueza social produzida viabilizam a intensificação da circulação de mercadorias, haja vista que quem trabalha não produz o que consome, dispendendo seu salário na aquisição dos mais diversos bens para a reprodução da sua vida. E, por sua vez, possibilitando a sobrevida do capital ao azeitar seu mecanismo de reprodução ampliada.

Todavia, se de um lado a escalada sem precedente de ataques e difamações à Justiça do Trabalho e à legislação trabalhista em larga medida se sustentam na ignorância acerca do papel estrutural do Direito do Trabalho e sua efetividade - na forma do acima exposto -, de outro decorre do uso deliberado e de má-fé da mistificação das funcionalidades juslaborais pela carência de investigação e difusão de informações sobre a história juslaboral. É esta a hipótese que aqui lançamos e pretendemos explorar: a carência de subsídios históricos para dar sustentação aos registros de memória que vocacionam o Direito do Trabalho, conferindo-lhe seu particularismo (BARBAGELATA:1996), é elemento fundamental à fragilização da Justiça do Trabalho, levando ao aprofundamento de sua penúria - que é, sabemos, a penúria do Direito do Trabalho. Passemos a demonstrar essa miséria teórica, tão funcional às intenções deliberadas de afrontar a proteção jurídica de quem trabalha.

\section{HISTÓRIA DO DIREITO DO TRABALHO E SUA RELEVÂNCIA}

Inicialmente, parece conveniente traçar algumas linhas sobre a categorização e relevância da história do Direito do Trabalho enquanto campo de estudo e pesquisa.

Entendemos por história do Direito do Trabalho, tal qual Bernard Edelman (2016; p. 19), aquilo que o advogado francês aponta como uma "'história jurídica' do movimento operário", "uma 'história' que se apresenta como o ajuste permanente da relação capital/trabalho na própria estrutura da lei, ou melhor, que considera a relação capital/trabalho uma relação jurídica, uma relação entre "sujeitos"”, ainda que não exclusivamente se reduza à compreensão de que tal relação guarde essencialidade jurídica. Uma trajetória dinâmica, que apenas acidentalmente tangencia os marcos da legalidade, do direito positivado, que mais se atenta às próprias inflexões da correlação de forças e da luta de classes do que outras determinações. Assim, o resgate histórico do Direito do Trabalho é o resgate da luta das trabalhadoras e trabalhadores na sociedade capitalista. Lutas que,

2 Referida dualidade de existência aponta, de um lado, às condições materiais mínimas para reprodução da vida social, e de outro, à existência enquanto classe, no processo de luta de classes, utilizando-se da compreensão teórica de Lukács (2003) de "classe em-si" e "classe para-si". 
invariavelmente, deram-se pelo e por o Direito do Trabalho, sendo certo outras tantas se colocaram até mesmo contra o próprio direito ${ }^{3}$.

Nossa proposição de leitura se coloca, ao revés do que pode uma compreensão positivista-normativista e empobrecida projetar à história juslaboral, na compreensão de que a sociedade contemporânea é fraturada pela divisão de classes - leitura compartilhada com toda uma série de linhas teóricas, inclusive com a Doutrina Social da Igreja -, assentando seu processo de dinamização na centralidade do conflito entre estas classes - fruto da sua particular apreensão materialista-dialética e histórica. Desse modo, a história - assim como a história do Direito do Trabalho - só pode, aos nossos olhos, ter uma adequada compreensão se descolada de um encadeamento cronológico simples e puro de textos normativos, indo à fundo nos processos materiais e políticos que determinam a conformação desses instrumentos legais.

Assim, compreender as especificidades e funcionalidades da proteção jurídica de trabalhadores e trabalhadoras, bem como de suas organizações de classe, reclama, necessariamente, apoderar-se desse monumento que são as memórias, trajetórias, embates e pessoas que animaram o enfrentamento classista por gerações e gerações, não obstante possam ter passado aos anais da história como anônimas.

É claro que esta forma de apreensão não se limita ao materialismo-dialético. Esta é a lente que elegemos, por plúrimas afinidades, para voltar nossos olhos à realidade. Ocorre que, indiferentemente da corrente teórica que se proponha a tal mister, a busca por uma compreensão totalizante, ampliada, amparada na infinidade de referências e determinações que compõem o concreto se faz necessário, sob risco de empobrecer e obnubilar parte dos próprios fazeres históricos. É nesse vício que recaem, em regra, as proposições de leitura idealistas e positivistas-normativistas.

A atenção a estes aspectos passa, por vezes, desapercebida pelos doutrinadores trabalhistas. Talvez por essa razão o desprestígio das narrativas históricas, tomadas de forma protocolar - mecanicista, positivista e distorcida - ou mesmo escanteadas por parcela daqueles que se dispõem a pensar o Direito do Trabalho. Até autores sensíveis ao interesse da classe trabalhadora recaem nesse tipo de problema, como se denota de Carlos Henrique Bezerra Leite (2008; p. 17-19), que em seu curso em dois volumes - donde o primeiro, que versa sobre Teoria do Direito do Trabalho e relação de emprego, contando com mais de quatro centenas de páginas - dedica nem mesmo três folhas à temática. Já Homero Batista Mateus da Silva (2015), em seu Curso de Direito do Trabalho aplicado de dez volumes, não obstante direcione o primeiro tomo ao trato da Teoria do Direito do Trabalho, não sistematizará uma linha acerca da temática.

Questionamos: como aplicar o Direito do Trabalho sem conhecer sua história?

Felizmente, há sinais em contrário. É o exemplo da recente obra de Jorge Luiz Souto Maior (2012) (2017), que inaugura uma escola paulista amparada densamente em estudos históricos e já faz render frutos. São exemplos seus volumes do Curso de Direito do Trabalho, que dedica ao estudo da história do Direito do Trabalho no mundo e no Brasil, e a produção das obras coletivas e 3 Exemplo disso se encontra no período heróico do gérmen juslaboral brasileiro, na virada dos sécs. XIX para o XX, em que as perspectivas de luta operária se davam a partir de um registro revolucionário pautado pelo anarquismo e o anarcossindicalismo, tendências que não reconheciam no Estado burguês um interlocutor social e que não colocavam dentre suas pautas a consagração de direitos, senão a subversão, por completo e de imediato, da ordem capitalista. 
individuais resultantes das atividades do Grupo de Pesquisa Trabalho e Capital (GPTC-USP) por ele criado e coordenado. Mas não só. Uma série de outras leituras se colocam a anunciar, ainda que não de forma sistemática e em volume, a esperada lucidez no trato histórico juslaboral, como veremos no item a seguir.

É nesse conjunto de linhas que reputamos residir o lampejo de esperança que serve aos juízes, ainda existentes em Berlin, sustentar sua defesa do Direito do Trabalho dentro de suas particularidades históricas.

Partindo deste trabalho de investigação coletiva da história e, tomando leituras críticas já feitas por estes teóricos e outros, é que se poderá repensar a Teoria do Direito do Trabalho a partir da luta de classes, forjando uma Teoria Crítica do Direito do Trabalho que, em sua radicalidade - usando da chave marxiana exposta na Introdução à Crítica da filosofia do direito de Hegel ${ }^{4}$-, não expresse outra coisa que não a ida à raiz do Direito do Trabalho: as mulheres e homens que o constroem em sua prática, e não aqueles investidos de poder que sacralizam em texto a matéria juslaboral.

Para tanto, desmistificar, em diálogo, as leituras hegemônicas é matéria que se faz imprescindível.

\section{A NARRATIVA OFICIAL DA OUTORGA COMO INDUTORA DA MISTIFI- CAÇÃO HISTÓRICA JUSLABORAL}

Nosso intuito se revela aqui, todavia, em aproximar as problemáticas gerais e abstratas, de concepção, à nossa realidade. Assim, evidenciar no caso brasileiro esta característica de fruto da luta de classes que o Direito Laboral possui importa, em um primeiro momento, desconstruir aquilo que ficou conhecido uma narrativa oficial do Direito do Trabalho.

Primeiramente, é conveniente destacar que é muito difícil falar na existência de uma historiografia oficial do Direito do Trabalho - como também o é, no Brasil, tratar de historiografia oficial do direito $^{5}$ - por serem escassas e pouco pujantes as tentativas de se costurar os elementos que dão o tom ao processo histórico. As poucas experiências de estruturação substanciosa da historiografia juslaboral pátria, como é o caso do supracitado texto de Souto Maior (2017), não guardam qualquer pretensão de oficialidade.

Daí parecer-nos mais apropriado mencionar a existência de uma narrativa oficial sobre a gênese do Direito do Trabalho no Brasil - sobremaneira a partir das consistentes leituras de Angela de Castro Gomes (2005) e de Adalberto Paranhos (1999) -, e não propriamente uma historiografia oficial justrabalhista, caracterizada pelo que Luiz Werneck Vianna (1989; p.87-152) convencionou chamar de "ideologia da outorga". Ou seja, a compreensão de que o Direito do Trabalho é uma concessão do Varguismo ao então ascendente operariado industrial urbano brasileira, marcado pela

4 Na sua Introdução à Filosofia do Direito de Hegel, escrita e publicada após o texto original, nos Anais Franco-Alemães, cunhará a síntese de que "ser radical é agarrar a coisa pela raiz. Mas a raiz, para o homem, é o próprio homem”, (MARX: 2015; p. 151).

5A questão foi frisada, aliás, por Ricardo Sontag, em banca de avaliação de tese doutoral de Victor Hugo Criuscolo Boson, em 16.01.2019, junto à Faculdade de Direito da Universidade Federal de Minas Gerais. 
Sobre os usos da miséria historiográfica e a relevância da investigação história na aplicação do direito do trabalho SEFERIAN, G.

percepção e premonição do ditador e pelos seus anseios de afirmação protetiva universal - que jamais ocorreu.

Esta concepção - em que pese tenha contemporaneamente passado por uma série de questionamentos por esta ainda nascente historiografia juslaboral (SOUTO MAIOR: 2017; p. 252-255) - contamina visceralmente a produção teórica trabalhista brasileira. Desse modo, dentre as parcas elaborações que, desde priscas eras, se voltaram a traçar prolegômenos históricos de temas juslaborais diversos - em regra em manuais, cursos e introduções de artigos -, se deixaram aderir por esse discurso oficial, forjado na pequena política e propagandeado pela utilização da máquina pública e da propaganda oficial getulista.

Ilustremos com alguns desses casos.

Segadas Viana, por exemplo, reconhece a cisão classista entre proletários e capitalistas no ascender do capitalismo (VIANNA:1993; p. 35), mas irá personificar no Estado a tarefa de dirimir as desigualdades imanentes do desenvolvimento deste modo de produção ${ }^{6}$ :

Era ao Estado, força suprema, acima de grupos e interesses, que teria de caber essa mediação de equilíbrio, opondo-se à ação de um grupo de indivíduos contra outro ou outros grupos. Como órgão supremo do direito, o Estado deveria, na nova concepção, tornar-se instrumento da justiça - da justiça da sociedade - intervindo como representante dos interesses coletivos para conter e reprimir os interesses individuais privados e manter o equilíbrio entre os diversos fatores da produção e, portanto, uma melhor repartição das riquezas, base do bem-estar social. (VIANNA: 1993; p. 38-39) ${ }^{7}$

A seu ver, o Estado, para além de ente apartado dessa conflituosidade, assumiria papel de sujeito, de terceiro interventor, como se não guardasse posição em favor de uma das classes beligerantes. Não por outra razão, antecedam em sua narrativa histórica os tópicos sobre o advento da "doutrina intervencionista" e sobre a Doutrina Social Católica ao item sobre os movimentos reivindicatórios dos trabalhadores (VIANNA: 1993; p. 40-41). Isso, vale dizer, ao tratar da história juslaboral nos países centrais da ordem capitalista. A constatação que inverte a dinâmica de formação histórica do Direito do Trabalho mostra-se mais evidente quando passa Segadas Viana a tratar o caso brasileiro. Inicia seu capítulo sobre a "Evolução do Direito do Trabalho" ressaltando que $6 \mathrm{O}$ fato se repete em outros tantos teóricos trabalhistas. É o que vemos, por exemplo, em Wagner D. Giglio (2011; p. 16), ao afirmar que "o surgimento de conflitos, na vida em sociedade, é inevitável. O mundo do trabalho não foge à regra, mas o Estado liberal da época primitiva não interferia nas controvérsias entre patrões e empregados. Em casos mais graves, eclodiam greves. A solução dependia da lei do mais resistente: cediam a algumas reivindicações os empregadores, para retomar a produção e evitar maiores prejuízos. Ou desistiam delas os trabalhadores, não suportando a falta de remuneração por mais tempo. Com o decurso do tempo e o recrudescimento dos conflitos trabalhistas, os governantes se deram conta do empobrecimento da nação, causado pelas greves, e o Estado liberal abandonou sua posição de alheamento e passou a interferir nesses movimentos, impondo normas para sua solução".

7 A elaboração expressa, em larga medida, a síntese ideológica da busca pela paz social, uma dos pilares da Doutrina Social da Igreja, sustentáculo dominante da elaboração institucional do Direito do Trabalho brasileiro, presente no art. $8^{\circ}$, caput, da CLT: “Art. $8^{\circ}$ - As autoridades administrativas e a Justiça do Trabalho, na falta de disposições legais ou contratuais, decidirão, conforme o caso, pela jurisprudência, por analogia, por eqüidade e outros princípios e normas gerais de direito, principalmente do direito do trabalho, e, ainda, de acordo com os usos e costumes, o direito comparado, mas sempre de maneira que nenhum interesse de classe ou particular prevaleça sobre o interesse público.”, g.n.. 
Sobre os usos da miséria historiográfica e a relevância da investigação história na aplicação do direito do trabalho SEFERIAN, G.

dentre suas "forças criadoras", existiriam “movimentos ascendentes" e "descendentes". Os primeiros, seriam caracterizados pelas demandas e lutas sociais. Pondera Segadas Vianna (1993; p. 55):

Se esta [luta social foi, em quase todo o mundo, a causa e origem da legislação do trabalho, em alguns casos - e neste se pode incluir de nosso país - não é o chamado 'movimento ascendente' que vai gerar a ação dos parlamentos, e sim o 'movimento descendente' que resulta de uma ação de cima para baixo, do Governo para a coletividade.

E coroa:

Nos movimentos descendentes, do qual é exemplo frisante nosso país, as características são:

a) inexistência de luta, sem que isso indique a ausência de uma questão social, embora latente;

b) falta de associações profissionais;

c) os grupos sociais são ainda inorgânicos;

d) não há atividades econômicas que exijam massas proletárias densas." (VIANNA: 1993; p. 56)

Descartando todo o processo de convulsão social existente no país antes e durante o Varguismo, isso para além do conjunto de intensas lutas sindicais que no curto período de democracia existente entre 1945 e 1964 ensejaram consideráveis avanços na proteção de trabalhadoras e trabalhadores no ordenamento jurídico pátrio, mostra Segadas Viana, a quem dúvidas pudesse ter, sua adesão à narrativa oficial. Afinal, como poderíamos falar em inexistência de luta em um país que vivenciara, na Primeira República, a Revolta da Chibata, do Contestado e o Tenentismo? Greves gerais em São Paulo e Rio Grande do Sul, em 1917, e no Rio de Janeiro, em 1912 e 1918 ? Isso para não tratar da Revolta da Vacina e Canudos, que muito embora não tivessem natureza propriamente trabalhista, deram corpo ao caldo social do período. Não seria melhor pensar, nesse caso, em invisibilidade ideológica do enfrentamento de classe?

Da mesma sorte, qual subsídio se pode ter quanto a falta de associações profissionais, ante as diversas organizações operárias e camponesas que pululavam no Brasil, que levaram até mesmo à elaboração de leis, no começo do séc. XX, visando sua regulamentação? Ante os infindos congressos, a volumosa imprensa operária, a crescente articulação comunista existente desde 1922? Talvez não fosse mais factível pensar Segadas Viana estar desconsiderando esse processo de auto-organização por conveniência com o regime que compôs organicamente?

Quanto a inorganicidade dos grupos sociais, soa-nos mais como um preconceito com a preponderância anarquista e anarcossindicalista da atuação política até meados dos anos 1920, responsável por arrancar as primeiras conquistas juslaborais no país, do que propriamente uma debilidade no envolvimento político-social.

Por fim, naquilo que se refere à carência de um operariado no país, é de se destacar não só uma eurocêntrica compreensão da luta por direitos trabalhistas, como também uma impressão bastante distorcida e idealista da realidade dos países centrais da ordem. É de se ter em conta que o processo de industrialização e, sobretudo, assalariamento populacionais passou a galgar espaços proporcionais no conjunto da população global apenas no curso do séc. XX, sendo certo que o Brasil, ainda que ingressando no processo de industrialização de forma um tanto quanto retardatária - isso pelo processo de desenvolvimento desigual e combinado do modo de produção capitalista (TROTSKY: 2007) (TROTSKY: 2011) -, já mantinha uma população urbana expressiva e um 
parque industrial nascente, ainda que bastante reduzida quando comparado com a pujança agrária. De toda sorte, esse contingente operário - se fosse o único que pudesse ser dignatário deste direito destinado ao conjunto de assalariados - mostrava-se cada vez mais numerosos.

Não por outra razão, não seja de se estranhar que nas 22 páginas que reserva à história do Direito do Trabalho no Brasil, não sejam aventadas menções às intensas lutas sociais havidas no país. Nenhuma linha foi dedicada às intensas greves, às efetivas conquistas que vieram a reboque de lutas e reivindicações, o nascente movimento operário

Jorge Luiz Souto Maior (2017; p. 126-140), amparado em escritos de Marcelo Badaró Mattos e Ramatis Jacino, demonstra que, ao contrário do propugnado, as dinâmicas sociais no período foram intensas, sendo inúmeras e massivas as greves, inclusive sendo deflagradas as já mencionadas greves gerais, como no Rio de Janeiro, em 1912 e em São Paulo, em 1917. Não coincidentemente, no último caso, o ano em que eclode o processo revolucionário na Rússia. De toda sorte, não se pode entender que as greves e os sindicatos "chegaram ao Brasil no início do século XX", como se fossem um raio em céu azul'. Se tanto, podemos falar na chegada de imigrantes europeus, que em verdade desde o séc. XIX já passavam a contar com o apoio da República para aportar em solo pátrio $^{10}$, podendo-se ver o papel dos europeus, articulando-se com pessoas escravizadas, na luta social pátria (VITORINO: 1999). Não foram transplantados da Europa sujeitos ou os mecanismos de luta, mas sim foram estes forjados pelos processos sociais particulares havidos no país, donde a migração teve parte importante.

Diante de tais fatos, como crer que Legislação Operária veio de cima para baixo?

Mas não é só. De outra banda, no escrito de Segadas Viana os nomes de parlamentares, teóricos e militares abundam. Faz revelar sua concepção de história: elitista e palaciana. Reputa ainda o redator do texto consolidado ser o interstício que vai de 1914 a 1930 um "período de inatividade legal”, sendo apenas nestes breves parágrafos que dedica ao fim da Primeira República que men-

8 Há de se fazer justiça que mesmo obras de teóricos conservadores, uma vez atentas a aspectos históricos, fazem revelar a marca do movimento operário nesse período. Vejamos a obra de Amauri Mascaro Nascimento (1978; p. 33): "Desde 1870 assinala-se a existência de jornais de tendência proletária. Agrupamentos, influenciados pelos modelos europeus, trazidos pelos imigrantes, aparecem. Em 1870 havia Ligas. Em 1890 surge o partido operário no Rio de Janeiro, presidido por José Augusto Vinhaes, líder ferroviário que força greves. Em Fortaleza em 1890, outro partido operário. Em São Paulo, em 1905, a Federação Operária. Difundiram-se os partidos socialistas com manifestos e programas contendo inúmeras reivindicações, não faltando a de 'tribunais arbitrais com 50\% de operários'. Na luta pelos seus ideais, os operários das fábricas e oficinas organizaram-se. O anarquismo encontra campo para as suas ações. Não são poucas as greves”. De toda sorte, Mascaro Nascimento, ainda que seja um dos juslaboralistas brasileiros mais preocupados com questões históricas, jamais elaborou trabalho de densidade sobre o tema, em regra reservando-se a repetir lugares comuns.

9 É o caso de Mônica Sette Lopes (2007, p. 53), na seguinte locução: “Greves e sindicatos chegaram ao Brasil no início do século XX e marcaram também aqui a idéia de conflito, de coalizão e de negociação que caracteriza a dinâmica do Direito do Trabalho em sua evolução formadora. Nessa esfera tampouco houve uma aprovação imediata das mudanças.".

10 "Nesta fase, o governo participa mais ativamente, pagando o transporte dos imigrantes até o Brasil e dando início ao período denominado de 'imigração subvencionada', em substituição à 'colonização', que ficou reservada ao período anterior, iniciado nos idos de 1850.” (SOUTO MAIOR: 2017; p. 90). 
cionará - de forma contraditória, imprecisa e vaga - questões atinentes a demandas sociais ${ }^{11}$. Não se atenta, porém, que é nesse período que passa a florescer - não obstante se intensifique a produção a partir de 1930 - ampla legislação versando sobre o mundo do trabalho, nas mais diversas tonalidades, passando até, após 1926, à competência federal o trato de sua produção normativa.

Não é Segadas Viana a única voz nesse sentido, porém.

É o que podemos verificar, por exemplo, da leitura feita pelo Ministro do Supremo Tribunal Federal Marco Aurélio Mello (2011; p. 33), ao esvaziar o conteúdo reivindicatório do Direito do Trabalho brasileiro, reputando-os à promessa de campanha de Getúlio Vargas:

A produção legislativa intensificou-se a partir de 1930, com a eleição do Presidente Getúlio Vargas, em cumprimento a promessas de campanha, especialmente o contido no Manifesto da Aliança Liberal de 1929. O marco inicial na sistematização dos direitos trabalhistas, entretanto, só veio à baila em 1943, com a Consolidação das Leis do Trabalho.

Descartando também o impacto da luta dos trabalhadores para a formação de uma justiça especializada trabalhista no país - desdobramento das conquistas do "direito material" trabalhista -, aduziu o Ministro do Tribunal Superior do Trabalho, nascido em Getúlio Vargas-RS e aposentado em 2018, João Oreste Dalazen:

Por isso, a rigor, os órgãos embrionários da Justiça do Trabalho não foram propriamente fruto de uma reivindicação social: foram fruto de uma ação governamental preventiva ante o mero receio de embates mais sérios que poderiam sobrevir entre o CAPITAL E O TRABALHO. Recorde-se que vivíamos, então, no plano político, sob a ditadura do Estado Novo do Presidente Getúlio Vargas. No campo trabalhista, um Brasil ainda rural engatinhava vagarosamente tentando alcançar a Revolução Industrial que começara na Inglaterra do Século XVIII e já chegara a todo o mundo civilizado (2011; p. 22).

Ignoram os Ministros serem estes direitos conquistados para e pela resistência e promoção de enfrentamento, em que pese tenha tido sua contraditória serventia de alicerce para o modelo de acumulação capitalista instalado no país na década de $1930^{12}$.

11 Ressaltará Vianna (1993; p. 62), inicialmente, que "a primeira guerra mundial (1914-1918) alertara o mundo inteiro sobre a importância que tinham as massas operárias e o poderio de que dispunham, quando o proletariado se unia para defesa de suas reivindicações. A revolução militar na Rússia, passando ao controle de Lenin, tomava um sentido de convulsão social, alarmando as nações ocidentais". E após, ressalta de forma branda aquilo que até mesmo às vistas com nevoeiro se poderia enxergar, amparado em constatações inexplicáveis: "Nesse período, justamente quando o País começava a se industrializar e o proletariado, sob influências internas e externas, ia adquirindo a consciência de classe, foi que se verificou menor ação, quer por parte do Governo, quer dos parlamentares. É que também nesse período o País atravessava grandes dificuldades políticas que culminaram em duas rebeliões militares (1922 e 1924)". Como, aliás, se as rebeliões tenentistas no Rio de Janeiro, São Paulo, Manaus e outras localidades não tivesse engrossado o caldo social que resultou em nossa legislação trabalhista...

12 Wilson Ramos Filho (2009; p. 186) perceberá esse fato, elencando que o primeiro período de governo de Getúlio Vargas não foi um momento de concessão de direitos, mas sim de tomada de consciência pela burguesia: "Neste sentido se pode afirmar que a ditadura Vargas, de 1930 a 1945 foi o período necessário para que o empresariado brasileiro se apercebesse da ambivalência peculiar ao direito do trabalho: ao assegurar direitos aos empregados, consolida e legitima o poder empresarial e o próprio sistema capitalista.". Para uma análise pormenorizada da situação, amparada sobretudo nas leituras de Chico de Oliveira, indicamos nossa leitura sobre o tema em AUTOR. 
Evaristo de Moraes Filho, de outro lado, é categórico e acertadíssimo ao considerar um "erro histórico, além de mera propaganda eleitoral, a frase feita de que o Brasil nada possuía nesse terreno" da luta proletária antes de 1930 (MORAES FILHO: 1978; p. 162). O mesmo autor, reconhecendo serem conquistas dos trabalhadores e trabalhadoras e uma "injustiça que se comete à massa operária" conferir a certidão de nascimento do Direito do Trabalho brasileiro a Getúlio Vargas, não deixa de atribuir também "aos grandes idealistas e lutadores que a defenderam e orientaram [a massa operária]; aos parlamentares, principalmente aos membros da Comissão de Legislação Social; e, finalmente, a alguns homens de governo" o papel na formação do Direito do Trabalho pátrio (MORAES FILHO: 1978; p. 161-162). De forma muito mais branda, por certo, o fato em parte se reflete no modo de exposição do autor, e o modo com que esse lê o Direito do Trabalho: nas páginas que narra a história da regulamentação das relações de trabalho no Brasil, sucessivamente, as referências aos atos normativos precedem as menções às dinâmicas sociais que as ensejaram, isso quando mencionadas (MORAES FILHO: 1978; p. 158 e seguintes).

Aqui, em nenhum momento, está a se desconsiderar o papel institucional e intelectual na forja juslaboral. Afinal, a dimensão ideológica e textual também é componente do fenômeno jurídico, articulando-se dialeticamente com sua expressão material. O que se coloca aos olhos da crítica é a ênfase de Evaristo de Moraes Filho, um dos mais eruditos e sensíveis juslaboralistas brasileiros, também impactada por essa prevalência institucionalista do Direito do Trabalho, ainda que em dimensão muito menos profunda.

Assim também é a posição do Ministro do Tribunal Superior do Trabalho, aposentado em 2012, Horácio de Senna Pires (2011; p. 126-127). Se de um lado diz que "afirmar que este arcabouço legislativo e jurisdicional foi uma dádiva do Estado Novo, um regalo de Getúlio Vargas ou simplesmente uma cópia servil da Carta del Lavoro, do regime fascista italiano, não passa de um feixe de equívocos históricos e sociológicos", de outro atribui a gênese do Direito do Trabalho não às lutas classistas, mas sim ao fato de que "o mundo já tinha vivido e sofrido o suficiente para saber que a prosperidade das nações passa necessariamente pela valorização do trabalho, pelo reconhecimento da dignidade da pessoa do trabalhador".

Essa posição parece pesadamente contaminada pela influência - que de fato existiu - da leitura de que o forjar do Direito Internacional do Trabalho e os compromissos brasileiros tomados com o Tratado de Versalhes, após as agruras da Primeira Guerra Mundial, viriam a impor esse estabelecer normativo. Ou ainda à Doutrina Social da Igreja, componente forte no pensamento do Ministro, que na sua juventude militou nos importantes movimentos da Ação Católica (AC) e de Educação de Base (MEB) (TST: 2012). Mais apropriada, porém, é a leitura de Souto Maior no sentido de que tanto a influência dos pactos internacionais - que acrescentamos, é motivada pela luta proletária no âmbito internacionalista, sobretudo diante dos receios do alastrar da onda revolucionária bolchevique - quanto da dinâmica de classes nacional são motivadoras do germe de nossa Legislação do Trabalho (SOUTO MAIOR: 2017; p. 489).

Tal qual Evaristo de Moraes Filho, Paulo Merçon (2010; p. 139) também se insere em uma senda crítica de leitura do Direito do Trabalho e reproduz leitura alheia à sua natureza classista. É o que se verifica quando projeta à lógica do modo de produção capitalista e ao advento das forças produtivas - e não propriamente na conflituosidade de classe - as conformações justrabalhistas: 
Essa [é] a lógica do modo de produção capitalista, fonte material medular do direito do trabalho, e que resiste aos avanços e metamorfoses do capitalismo nas últimas décadas. Se tal lógica irá sobreviver ao futuro, à automação crescente, à centralidade do conhecimento e da informação na produção da riqueza, só o tempo irá dizer.

Como se percebe, em regra, os textos trabalhistas - isso quando se preocupam de forma efetiva com a questão histórica - acabam traçando considerações sempre a partir do referencial idealista $^{13}$, normativista, e de forma um tanto quanto descritivas (BARROS: 2017; p. 53-67). Fazendo um paralelo - isso, claro, sem fazer qualquer comparação de enfoque ou densidade entre os descritivos históricos juslaboralistas e o historiador marxista inglês - e mudando o que deve ser mudado, podemos dizer o mesmo que Daniel Bensaïd (2008; p. 77) quando se confrontou com os textos de semelhante natureza redigidos pela conhecida pena de Eric Hobsbawn: esses estudos trabalhistas não prometem uma "história crítica", quanto menos uma "história historiográfica", que não dá conta das problemáticas das encruzilhadas do fazer político. Mostram-se, pois, como uma forma de história que naturaliza a transformação social, descolando-os do agir coletivo, e que, referenciando Walter Benjamin, tem "maior dificuldade para conceber o imperativo político de 'escovar a história a contrapelo".

São raras as posições distintas dessa linha majoritária. Afora Souto Maior, citado à exaustão e principal referência nesse particular, há que se mencionar que apenas fração da doutrina se atenta a tais elementos que reputamos essenciais. Por vezes, vale dizer, o fazem quase acidentalmente. Fatia da literatura trabalhista, mesmo sem projetar o cerne do fazer histórico ao enfrentamento classista o que é legítimo e relevante, até em razão de qualquer intenção de pensamento unitário soar de todo inadmissível, antidemocrático e pouco proveitoso para uma sociedade rica e plural - e sem atenção à acuidade metodológica - reconhecendo o receio de uso da terminologia consagrada na tradição e leitura marxistas -, ao enfrentar alguns temas torna explícita demais a "luta" travada entre as classes sociais, pelo que o diagnóstico comum aos materialistas se mostra inescapável. É o caso de Fayet Júnior e Fraga (2011; p. 293), ao mencionarem que "apesar das altas cifras relacionadas a acidentes ou doenças do trabalho, alguns teóricos evitam a expressão luta de classes. Entretanto, esses números revelam uma verdadeira guerra entre dois setores sociais diametralmente opostos".

Ainda que não por acidente, também de Francisco Milton Araújo Júnior (2014; p. 68), se perceberá nitidamente a dinâmica de classe que enseja a formação do Direito do Trabalho. Mesmo nos parecendo equivocada a associação exclusiva de sua leitura ao "Estado Social Democrata" em diagnóstico que em verdade poderia se estender a toda conformação estatal que não o liberal em sentido estrito -, ou por generalizar essa conformação para situações sócio-históricas que não a experimentaram - como é o caso do Estado brasileiro, já que não obstante tenhamos vivenciado o aflorar de normas regulamentadoras do mercado de trabalho, jamais poderia ser definido como de Bem-Estar -, fará o diagnóstico acertado no sentido de que "atrelado ao Estado Social Democrata que se desenvolvia na sociedade capitalista no pós-Segunda Guerra Mundial, a classe burguesa atua na neutralização do avanço das manifestações operárias com a concessão de ganhos salariais aos trabalhadores."

13 É o que se nota da compreensão estranha à luta de classe de Mauro Schiavi (2010; p. 361): "historicamente, o Direito do Trabalho surgiu como conseqüência de que a liberdade de contrato entre pessoas com poder e capacidade econômica desiguais conduzia a diferentes formas de exploração." 
Ainda que sem a pretensão de acuidade com o materialismo-dialético, mas com maior intencionalidade, é de lucidez imensa a posição firmada por Fábio Túlio Correia Ribeiro (2011; p. 33), no sentido de que "não há direitos concedidos, somente existem direitos conquistados"14. Historicamente precisa também a afirmação de Márcio Tulio Viana, Gabriela Neves Delgado e Helder Santos Amorim (2011; p. 56) ter sido o Direito do Trabalho o "primeiro e único construído basicamente pelos oprimidos". Luta por Direitos Sociais - e em especial trabalhistas - tida não só no campo das ideias, mas assumindo uma feição "pragmática", como quer o pesquisador e servidor técnico da Justiça do Trabalho Rubens Goyatá Campante (2011; p. 323-324):

A evidente falácia dessa suposição da igualdade de condições na competitividade social (cada vez mais acirrada) levou democratas e socialistas a atacarem o absenteísmo do Estado laissez-faire e o formalismo de seu poder judiciário, tão convenientes à dominação burguesa e tão omissos em relação à exclusão que esta trazia. Além de lutarem pela extensão e efetivação dos direitos políticos e civis, as forças democráticas e de esquerda começaram a se bater por uma nova ordem de direitos, chamados 'direitos sociais'. Tal luta foi não apenas teórica, mas pragmática, especialmente no tocante a um tipo de direito que, pela sua precedência e importância, chegou a ser, por um tempo, quase sinônimo de direito social, o Direito do Trabalho.

Boa compreensão também parece a de Rezende (2009; p. 124), que não só anuncia as determinações econômicas e sociais que levam às classes trabalhadoras ao enfrentamento para melhoria de condições de vida, como aponta ser o Direito do Trabalho uma concessão frente a estas convulsões sociais:

Isso se deveu à própria formação histórica do direito do trabalho que, como se sabe, surgiu como uma reação às convulsões sociais que foram engendradas pela Revolução Industrial no final do século XIX. O incremento da produção fabril, aliado à exacerbação dos princípios liberais antes consagrados pela Revolução Francesa de 1789, conduziu a classe trabalhadora a péssimas condições de vida, o que gerou reações revolucionárias como os movimentos sociais de massa de inspiração anarquista, socialista ou comunista, nas mais diversas vertentes, sem deixar de se apontar a própria doutrina social da Igreja. As convulsões sociais geradas pelo capitalismo industrial nos seus primórdios foram se avolumando e ameaçavam a própria sobrevivência desse sistema econômico. Assim, para seguir vivendo, o capitalismo industrial, que então dava seus primeiros passos, viu-se obrigado a ceder espaços às reivindicações dos trabalhadores. Ou seja, teve o capitalismo que aceitar que a classe trabalhadora plasmasse no seu ordenamento jurídico direitos de índole social a fim de que a tensão no seio da sociedade entre as duas forças envolvidas no processo produtivo atingisse um certo grau de tolerabilidade. Esta foi a fórmula encontrada pelo capital para que se viabilizasse, em certa medida, a manutenção do status quo e pela classe trabalhadora para embutir suas reivindicações na ordem jurídica vigente.

14 Amparando-se no Manifesto Comunista, o autor continua: "Verdade ainda maior, particularmente, quanto aos direitos sociais laborais, estratificados, em todos os tempos e em todas as latitudes, ao custo altíssimo da organização das classes obreiras e do embate duríssimo entre duas forças sociais historicamente antagônicas: os detentores dos meios de produção e os sem-posse", (idem; p. 34). E segue "A batalha travada para a consagração dos direitos sociais foi, e continua sendo, uma batalha levada a cabo no cenário da História, no qual esgrimem suas reivindicações - não raramente até a fronteira de suas potências -, as forças vivas da sociedade. De um lado, os integrantes das camadas privilegiadas, para os quais falar de direitos sociais seria uma afetação desnecessária que colocaria em risco a ordem jurídica; do outro, o imenso contingente humano de depauperados, excluído do gozo proporcionado pelo avanço do processo civilizador, que aspirava (e segue aspirando) ao alcance de mudança da ordem jurídica vigente. Claro está, destarte, que o aludido reconhecimento é, em seu cerne, não uma dádiva, senão uma conquista derivada da luta política" (RIBEIRO: 2011; p. 36). 
Ainda que não encontre dimensões monumentais como a proposta de Souto Maior, a leitura histórica de Magda Barros Biavaschi (2011; p. 88) mostra-se assaz coerente e, ainda que enxuta e esparsa, revela tremendo acerto. Talvez por conta de se tratar de uma das poucas juristas com grande sensibilidade para com as questões da memória da classe trabalhadora e da Justiça do Trabalho, e por certo em decorrência de seu acúmulo nos campos da economia e política, nos ensina que a relação simbiótica existente entre o capitalismo e o Direito do Trabalho vem desde seu germe, isso ao fazer despontar as condições materiais necessárias para seu surgimento:

\begin{abstract}
A inquietação localiza-se no Direito do Trabalho, em como vão sendo gestadas as condições materiais para seu nascimento. Processo que se dá pari passu ao da constituição do capitalismo. Daí o olhar voltar-se para o século XIX, com foco na segunda revolução industrial e na natureza do trabalho encontrado na grande indústria, que garantia a generalização do trabalho assalariado. Estavam constituídas as condições materiais para o nascimento de um novo ramo do Direito, que viria mais tarde. ${ }^{15}$
\end{abstract}

Acertadamente, reputa à luta classista empreendida pelas trabalhadoras e trabalhadores como conformadora fundamental da regulamentação jurídica da compra e venda da força de trabalho:

Concentrados nas fábricas, os trabalhadores resistiam. A essa luta seguiam-se outras. A
pressão dos trabalhadores, de suas organizações, de intelectuais, da Igreja, dos partidos
políticos, passaram a exigir uma regulação apta a limitar a ação predatória do capital. A
luta pelo sufrágio universal aproximava as massas. Os partidos começavam a canalizar as
reivindicações proletárias. Movimentos de resistência que impulsionavam a positivação
das regras de proteção ao trabalho (...). Daí que sua gênese não pode ser compreendida
apartada das lutas concretas e das especificidades que se dão em cada sociedade. No
Brasil, as condições histórias para seu nascimento estariam dadas no século seguinte.
(BIAVASCHI: 2011; p. 88)

Precisa a colocação da pesquisadora gaúcha, denotando que no plano internacional também o Direito do Trabalho se desenvolve de forma desigual e combinada pelas nações do globo, não seguindo uma mesma temporalidade ou uma identidade cronológica em um mesmo tempo do mundo.

O acerto destas leituras históricas vem, segundo Bensaïd (1999a; p. 80) e com amparo em Marx - que "não se entrega a esse gênero de especulações horarias" - do "apreender as contradições e os conflitos da época, onde se representa o efetivamente possível". Sua proposta é concebida a partir de um referencial próximo ao de Walter Benjamin, este que, segundo Michael Löwy (2005; p. 59), se "interessa, no passado," não principalmente pelo "desenvolvimento das forças produtivas, a contradição entre forças e relações produtivas, as formas de propriedade ou do Estado, a evolução dos modos de produção - temas essenciais da obra de Marx", mas sobretudo pela "luta até a morte entre opressores e oprimidos, exploradores e explorados, dominantes e dominados", dando centralidade ao elemento da luta de classe. É nesse esforço - de encontrar aquelas e aqueles 15 Também apropriado diagnóstico, em mesmo sentido, é o do magistrado e docente baiano Murilo Oliveira (2011; p. 63): “A questão central do modelo capitalista é, portanto, o monopólio por uma classe social dos meios de produção, impelindo a classe não-proprietária a vender sua força de trabalho, inclusive com cessão de trabalho excedente. Diferentemente dos modos de produção anteriores - que se pautavam em trabalho forçado (escravo, corveia, etc.) através da atuação do poder do Estado -, o capitalismo construiu um modelo de trabalho formalmente livre, mas que, pela não detenção dos meios de produção, realiza-se como trabalho socialmente imposto. Se a coação era baseada na lei, agora ela ocorre pela própria estrutura social e, assim, de modo invisível." 
que tombaram, ainda que anônimos, pela melhoria das condições sociais, econômicas e políticas de quem trabalha - que reside a prática de "escovar a história a contrapelo" - já invocada e cara expressão benjaminiana (BENJAMIN: 1994; p. 225).

Não parece haver dúvidas quanto a isso: só com isso as historiadoras e historiadores do Brasil a magistratura de Berlin - ou podemos fugir da expressão e já sermos mais explícitos, tratando-os por "magistratura do Trabalho"? - poderão seguir nutrindo esperanças de uma atuação livre, independente e teleologicamente determinada pela história juslaboral.

Ainda que tal tarefa de elaboração historiográfica já se coloque em curso, há muito de ser continuada. E mais grave: passa ela por diversos e imensos riscos, que se agudizam contemporaneamente, sobretudo no que se refere a uma metamorfose da ideologia da outorga que, dado o grau de desonestidade de seus prolatores, recai violentamente sobre o Direito e a Justiça do Trabalho.

\section{OS RISCOS DA METAMORFOSE DA OUTORGA E A NOVA OFENSIVA CÍNICA FRENTE AO DIREITO DO TRABALHO}

As linhas trazidas pelos poucos pensadores e pensadoras do Direito do Trabalho no que se refere à história do ramo jurídico são, ainda, parcas e insuficientes para fazer páreo à perenidade das distorções proporcionadas pela narrativa oficial da ideologia da outorga.

A adesão - nada inofensiva - a tal narrativa acabava apenas por cumprir um papel mistificador da realidade histórica, jogando para debaixo do tapete os processos de convulsão social que ensejaram efetivamente o desenvolvimento de tal arcabouço normativo, interditando a tomada de consciência das trabalhadoras e trabalhadores enquanto protagonistas de sua própria história, o que por si só já seria extremamente daninho à própria sustentação política do Direito do Trabalho.

Ocorre que a hegemonia de tal narrativa na compreensão sócio-histórica do Direito do Trabalho não é unívoca e estanque, sendo a dinamização da própria ideologia da outorga marca de sua afirmação. Esta passa a incorporar elementos outros, que a ela são estranhos, suscitando a utilização instrumental - e não pouco oportunista - deste corpo de fatores aderentes. O mais significativo e que mais riscos importa tanto à boa-fé dos debates políticos e historigráficos relativos à Legislação do Trabalho, por certo, é que equaciona cronologicamente a promulgação da CLT a uma suposta gênese juslaboral de natureza fascista.

Parece-nos haver uma metamorfose, uma transmutação, da ideologia da outorga tal qual ela classicamente se assenta, aparecendo, no trato usual e pouco erudito, a origem do Direito do Trabalho não mais como fruto de um ato de benevolência varguista, mas sim de uma cópia da Carta del Lavoro de Mussolini.

Essa referência associativa não é recente, e remonta já algumas décadas. Talvez a mais sofisticada e robusta delas, e não menos comprometida com a defesa dos interesses patronais - o que, por si só, não a faz desonesta -, seja a elaborada pelo professor carioca Arion Sayão Romita (2001), em sua obra "O fascismo no Direito do Trabalho brasileiro". O texto, em que pese intencionalmente formulado para promover o desprestígio do conjunto da Legislação do Trabalho visando sua flexibilização radical e completa, formula associações da Carta del Lavoro com o Direito do Trabalho brasileiro com a densidade mencionada apenas no que se refere à esfera da regulamen- 
tação sindical. Em todos os demais campos juslaborais, as ligações são frágeis e forçosas. O reconhecimento dessa prevalência do impacto corporativo no campo sindical é reafirmado por Romita (s/d) em outra discussão:

Não se trata de reavivar o pueril debate sobre a questão de saber se a CLT é "cópia" da Carta del Lavoro: basta comparar a extensão de uma e de outra, pois enquanto a CLT contém 922 artigos, a Carta italiana consta de 30 declarações.

Ao que consta, jamais alguém formulou semelhante sandice, pois a tese da "cópia" raia pela absurdez, ante sua evidente fragilidade.

A intenção ancestral de Romita passava por “jogar o bebê com a água suja”, para nos utilizarmos de outra expressão popular. Ocorre que, tudo que se viu desde as primeiras contrarreformas no texto Consolidado até os dias de hoje, foi em verdade o sacrifício do bebê da proteção individual em prol da manutenção da banheira com as águas turvas. O que denunciou Romita haver, de fato, de fascistizante, corporativista ou autoritário na CLT, segue existindo. Os demais registros Consolidados em nada são a ela tributários, sendo, na verdade, caudatários das demandas históricas do movimento operário brasileiro, ou das sínteses políticas das classes proprietárias para refrear a ebulição dos trabalhadores e trabalhadoras.

Em tempos em que a miséria da intelectualidade é objeto de elogio e a seriedade na compreensão de mundo causa calafrios, a assunção deste Cavalo de Tróia lançado academicamente por Romita reaparece não mais erguido em madeira, mas em papel, na boca de toda sorte de apologetas do desmonte da Legislação do Trabalho enquanto elemento de favorecimento aparente ao capitalista individual. Deixam de ter em conta, porém, que sistemicamente, o fim deste mecanismo de garantia jurídica de renda às classes trabalhadoras seria o catalisador do processo de crise que já hoje se experimenta, e pelas linhas econômicas e políticas que se anunciam, pouco tendem a se alterar que não em profundidade.

E é justamente no cenário de mistificação intelectual e apropriação desonesta desse gancho resultante da obra de Arion Romita que, há algum tempo, como reforço discursivo para as empreitas de precarização do Direito do Trabalho, passou-se a ver na esfera pública o crescente vociferar contra a Legislação do Trabalho alcunhando-a de fascista. Ocorre que o tema, tomado anteriormente com toda honestidade intelectual por Romita - que, em que pese antípoda de nossa linha de pensamento, deve ser reconhecido como pesquisador sério -, aparece instrumentalizado deslealmente no jogo acelerado jogo do vale-tudo para imposição das agendas regressivas no campo juslaboral.

Fiquemos com alguns exemplos.

No curso dos debates sobre o Projeto de Lei n. 6.787/2016, que resultaram após aprovação no Congresso Nacional na Lei n. 13.467/2017, o relator da proposta, Rogério Marinho (PSDB-RN), em diversas circunstância usou a adjetivação para tratar do arcabouço protetivo que intentou desmontar. Ainda que tenha anunciado que elementos estruturantes do modelo sindical pátrio, a exemplo da contribuição sindical, são "uma herança fascista que já dura 70 anos" (ESTADÃO: 2017) - o que é um fato -, isso ao buscar de forma oportunista a extinção deste modelo de arrecadação sem mexer em qualquer outra referência de sustentação do Sindicalismo de Estado brasileiro, em nítido intuito de fragilização das entidades sindicais, ampliou seu espectro de abrangência desqualificadora em outras declarações. É o que se nota em fala propalada uma semana antes da supraexposta, em 
12 de abril de 2017, em que mencionou que "inspiradas no fascismo de Mussolini, as regras da CLT foram pensadas para um Estado hipertrofiado, intromissivo, que tinha como diretriz a tutela exacerbada das pessoas e a invasão dos seus íntimos" (EXAME: 2017), sem fazer distinções entre o trato do Direito Coletivo e Individual do Trabalho, em que pese suas flagrantes distinções de influência.

Ainda que tenha servido de vetor apenas inicial dessa querela que, como reconhece Romita, é não só pueril como insana, serviu de estímulo à reprodução, em rádio, televisão e sobretudo nas redes sociais de associações pouco ortodoxas e bastante pejorativas entre a Consolidação das Leis do Trabalho e o fascismo.

A intenção de Rogério Marinho rendeu efeitos. Tanto é verdade que o discurso de modernização da CLT e abandono de sua carga fascista triunfaram politicamente, sobremaneira diante da carência de resistências do conjunto das classes trabalhadoras frente a tal ofensiva. A CLT, já tão alterada, como cansou de expor Jorge Luiz Souto Maior, após a Lei n. 13.467/2017 acaba por ser mutilada em uma série de seus aspectos já então alterados ou inalterados, sendo impossível tratar da mesma forma, ou verificar uma mesma essencialidade de seu texto, antes e depois de 11 de novembro de 2017.

Ocorre que, em que pese a legislação trabalhista tenha passado por impactos gigantescos recentemente, bem-sucedida que foi a ofensiva do capital frente aos direitos historicamente conquistados pelas classes trabalhadoras, não há qualquer sinal de que as classes proprietárias deem-se por satisfeitas com esse passo no caminho ao retrocesso social. O Direito do Trabalho a que hoje se voltam contra é outro, e não foi nem mesmo colocado a teste para demonstrar sua incapacidade de resolução das mazelas sociais a que se dispôs enfrentar - máxime os altos índices de desemprego.

Mesmo sendo outro o Direito do Trabalho, o argumento de ataque segue o mesmo, haja vista que, como bem denunciou Souto Maior (2019), segue sendo um bom ardil retórico.

É o que se pode verificar na primeira declaração pública proferida por Paulo Guedes em sua incorporação ao governo recém-eleito. Durante a cerimônia de transmissão de cargo - na verdade, na investidura de cargo novo, haja vista jamais houve concentração tamanha de poderes a um ministério como hoje se dá com o da Economia, bem como com o da Justiça e Segurança Pública -, declarou que "o governo democrático vai inovar e abandonar a legislação fascista da Carta del Lavoro" (O GLOBO: 2019).

A frase, por si só, suscita uma série de discussões, e cada uma de suas palavras proferidas por Guedes poderia ser colocada em questão. Desde a natureza democrática do mandato - fragilizada em demasia por declarações verborrágicas do então candidato à Presidência quanto a perseguição de opositores, que, felizmente, não revelam a prática até o momento do governo eleito -, passando pela suposta "inovação" - que repete a discursividade vazia que há décadas ataca o Direito do Trabalho -, chegando à "qualificação" do Direito do Trabalho enquanto "legislação fascista da Carta del Lavoro".

Quanto a este último ponto, vale dizer que hoje a alegação faz ainda menos sentido que outrora. Considerando ser o traço forte de vinculação da CLT com a Carta del Lavoro, ou com resquícios corporativistas, a organização sindical pátria, a rasteira dada na contribuição sindical pela Lei n. 13.467/2017 mina a continuidade da sustentação de tal discurso. 
De forma temporânea e imediata, Jorge Luiz Souto Maior (2019) confrontou a alegação do super-ministro e denunciou o caráter exclusivamente retórico de tal empreita:

\begin{abstract}
Muito rapidamente (porque essa conversa é bastante cansativa), vale lembrar que a CLT (o Decreto 5.452/43), como o próprio nome diz, é uma Consolidação das Leis do Trabalho que já existiam no Brasil e que foram assim formalizadas em um longo processo de reivindicações e embates entre empregados e empregadores. Leis trabalhistas no Brasil existiram desde a Primeira República e regulavam as relações de trabalho no período, sobretudo, as normas coletivas. Além disso, dos seus 921 artigos, continuavam em vigor, em 2016, apenas 188 artigos. A CLT, ao longo de sua história, foi alterada em todos os governos, com exceção de Jânio e, em 2017, sofreu uma profunda modificação, com a denominada "reforma" trabalhista, que atingiu mais de 200 de seus dispositivos. Ou seja, a tal CLT fascista, cópia da Carta del Lavoro de Mussolini, é uma figura mitológica, que sempre serviu aos argumentos retóricos de ataque aos direitos dos trabalhadores, que estão muito longe de ser dádivas do Estado. A Carta del Lavoro, inclusive, de 1927, foi uma Carta de Princípios, com 30 artigos, do governo fascista de Mussolini, que em nada se assemelha aos 921 artigos iniciais da CLT, a não ser quanto à vinculação do sindicato ao Estado, mas essa parte da CLT, prevendo essa vinculação, chegou a ser revogada, integralmente, em 1946, no governo de José Linhares e foi revigorada no governo de Gaspar Dutra, em 1946. De todo modo, essa vinculação foi juridicamente rompida desde 1988, com a promulgação da atual Constituição.
\end{abstract}

A esse conjunto de profundos argumentos lançados por Souto Maior, soma-se a percepção do cinismo, expressão forte da ideologia em nossos tempos (SLOTERDJIK: 2012). É inegável que, de uma forma ou outra, seja pelo conjunto de alegações polêmicas, pela verborragia autoritária, pelas linhas militarescas inegáveis, pelo nacionalismo entreguista de matriz capitalista, diversos opositores de Jair Bolsonaro não pouparam esforços em associar seu ascenso eleitoral - ao qual Paulo Guedes teve ligação orgânica, colocando-se como assessor mais influente do então candidato - ao fascismo. Por certo não é essa a forma que preferimos ver seu governo, nem mesmo associando sua afirmação como pós-fascista, na definição de Enzo Traverso (2016), por guardar particularidades e nuances distintas do ascender da extrema direita europeia. Todavia, há justificativas para aqueles que assim querem definir o atual governo e, indiferentemente do espectro político em que se encontre, ninguém parece gostar da associação com um regime que, para além de antidemocrático, se alinhou com o projeto político mais perverso da história na meia-noite do século XX.

Soa funcional, assim, com nítidos intuitos de depreciação, projetar ao outro, ou ao objeto de interesse do outro, a alcunha de fascista. Assim como de ideológico. Ocorre que, fascista ou não, tal discurso é da mesma maneira ou ainda mais profundamente ideológico quanto ao dos defensores da CLT, isso em razão de expressar uma Weltanschauung, uma "visão social de mundo" particular, associada ao conjunto ou classe social (LÖWY: 1985) que reputa à matéria juslaboral imediato interesse protetivo.

Retomemos aqui a temática da historiografia carente - para não dizer inexistente - do Direito do Trabalho no Brasil. Esta, na forma como vem se erigindo, jamais conseguirá legitimar a associação da CLT com o fascismo. Romita, o melhor dos entusiastas da tese, não conseguiu fazê-lo. Jamais se poderia cogitar que aqueles amparados apenas na retórico possam dar conta dessa difícil tarefa.

Todavia, porquanto a cantinela da "CLT fascista" perdurar, haverá campo para corroer a proteção juslaboral na esfera individual, que nada tem de fascista, merecendo ser enfrentada. 
Para tanto, entendemos essa etapa passar por dois momentos.

O primeiro, é o reconhecer o que há de fascista na CLT, e expurgá-lo. Ora, se há algo que remete a uma tradição corporativista no texto Consolidado, e que de fato guarda correlação com a Carta del Lavoro, passa pela organização sindical. Esta, porém, como já frisamos, é um dos únicos pontos do texto do Decreto n. 5.452/43 que - em que pese entendamos não tenha sido recepcionado pela Constituição de 1988 - não comportou alterações significativas desde sua promulgação, exceção feita à extinção da contribuição sindical dada com a Lei n. 13.467/2017. Ou seja, tudo que se alterou na legislação do trabalho com fito de implementar uma agenda neoliberal - avant la lettre, na ditadura empresarial-militar, ou em sentido estrito, sobretudo desde a década de 1990 -, ao ampliar a flexibilização na contratação, salvaguardar as margens de lucro, atender aos interesses patronais, e, logo, minorar a proteção de quem trabalha, manteve inabalada o tal restolho fascista.

De fato, podemos dizer que não temos nenhum acordo com o arranjo sindical brasileiro. Que seja alterado. Mas em que sentido? De afirmação de liberdades plenas? Aderindo à bandeira libertarianista posta pelo governo eleito? Que assim seja!

Lançamos um desafio, pois!

Acabemos com o que a CLT tem de fascista. Tiremos todo o expurgo autoritário, marcado pela lógica do controle político das entidades de classe, para proporcionar que os sindicatos se organizem pautados na mais estrita e absoluta liberdade sindical. E não só estamos aqui falando do oportunista e perverso extinguir da contribuição sindical, exclusivamente. Acompanhando tal alteração, o indispensável é que institutos como a unicidade sindical, a necessidade de registro junto à administração pública - até o início do governo Bolsonaro, realizado junto finado octagenário Ministério do Trabalho, e doravante feito junto ao Ministério da Justiça e Segurança Pública -, o controle de estatutos, as intervenções judiciais, entre outros traços, sejam da mesma forma extintos, para que passe o Estado apenas a intervir na práxis sindical em situações em que se verifiquem ingerências abusivas entre sindicatos, coibindo práticas antissindicais. Tudo na mais completa harmonia com as Convenções n. 87 e 98, da Organização Internacional do Trabalho.

E este desafio será aceito? Cremos que não. E caso isso se confirme, a contradição com a lida do tão propugnado "Estado mínimo" se mostrará irresolúvel, haja vista que este, como sempre, se seguirá pujante onde convém aos interesses do grande capital, que segue dando o tom da política econômica no país, agora de forma um pouco mais descarada.

Já o segundo ponto proposto passa justamente pelo revigorar histórico do Direito do Trabalho, que deve ser estimulado e ampliado a todo custo.

Em regra, a história tem sido chamada a jogo, aliás, única e exclusivamente para justificar suposta caducidade da legislação trabalhista pátria, que deveria ser "modernizada" - como também pretende o discurso oficial do Governo Federal brasileiro, alegação que remonta tanto Dilma, Temer e Bolsonaro. Mal sabem que a nossa legislação trabalhista de "moderna" tem muito", so-

16 Interessante é aqui a leitura de Samir Soubhia (2010; p. 93), no sentido de que "Podemos sem sombra de dúvida dizer que o direito do trabalho foi um direito criado e desenvolvido essencialmente no século XX, daí porque ostenta algumas novidades em relação ao direito comum e seus brocardos milenares, ainda no limiar deste Século XXI. Vemos, portanto, que enquanto outros diplomas legais sofrem sucessivas e substanciais mudanças, no intuito de tornarem-se modernos, práticos e efetivos, a CLT é uma jovem senhora que pouco muda sua forma de pensar, porque já nasceu moderna, mas prima por manter sua integridade intelectual." 
bretudo quando consideramos a leitura feita por Henri Lefebvre (1969), no sentido da modernidade se caracterizar por este processo em que o capitalismo hoje passa ao não se assentar, mas a intensificar suas dinâmicas internas de transformação, em contrapartida a um período "clássico" e liberal - dado na Europa no curso do séc. XIX, e que podemos aqui colocar ter ido até as décadas de 1920 e 1930.

Mas não é a essa "história" que fazemos remissão, de um senso comum empobrecido que liga o histórico ao apego à ancestralidade, ao ruído do anacronismo. Estamos aqui a falar da real compreensão das dinâmicas sociais, da feitura da história desde as massas, e pelos interesses dessas massas. Da história que não foi escrita, mas que mesmo subterrânea, é ouvida. Que mesmo que tente ser silenciada, é ensurdecedora. A história que, como a toupeira - para nos utilizarmos da figuração trazida por Shakespeare, Marx, Luxemburgo e Bensaïd - um dia irromperá da terra e trará à luz tudo que há muito cavou.

Por quanto esse sair à luz não chega, é dever que vocalizemos os interesses dos que não podem se colocar. E o Direito do Trabalho nasce para isso, para incidir em um campo burguês por essência e natureza (PACHUKANIS: 2017), e expressar o interesse das vencidas e vencidos da história. Sem que ouçamos esse conjunto social, sem que os atendamos, de nada servirá o Direito do Trabalho.

Em suma, respondamos: como fazer para colocar oposição a tal narrativa oficial, degenerada quando comparada à original, e ainda mais perversa que a primeva? Como viabilizar que os juízes e juízas do Trabalho no Brasil sigam servindo de objeto de esperança, e não de descaso ou decepção pelas classes trabalhadoras? Apenas pelo fomento da história. Afinal, não há como compreender as funcionalidades e usos do Direito do Trabalho sem se socorrer de seu efetivo forjar prático, e não apenas textual.

\section{CONCLUSÃO}

Concluímos, assim, de que nada adiantam juízes e juízas em Berlin - ou no Brasil! - quando não temos historiadores e historiadoras. Enquanto restarem estes últimos, subsistirá uma magistratura que no acentuar da conflituosidade social, do avançar dos ataques à Justiça do Trabalho, no tensionar da correlação de forças, não se acovardará pela sustentação de séculos de lutas sociais que desembocam, contemporaneamente, neste arcabouço jurídico protetivo que, tão pisoteado e de reclamada urgente aplicação, se constitui enquanto Direito do Trabalho.

A crença na história, porém, se coloca dentro da mesma referência que à da magistratura: ambas cumprem seu papéis, inclusive se apoiam mutuamente, porém não são suficientes para a consecução plena de um horizonte de enfrentamento radical às mazelas social. Não há Justiça redentora, como da mesma forma não há redenção motivada por uma História da mesma sorte maiúscula e universal, como aponta Daniel Bensaïd (1999b).

A saída da crise do capital passa pela afirmação radical do Direito do Trabalho. Qualquer alternativa que proporcione o aprofundamento da precarização, a fragilização das relações de trabalho, a minoração da participação das trabalhadoras e trabalhadores na divisão da riqueza produzida ou a intensificação dos ataques às condições de saúde e segurança de quem trabalha só tendem a 
aprofundar a barbárie do capital. Defender o Direito do Trabalho e sua aplicação dentro de seus marcos históricos de proteção é condição de existência para quem trabalha e para quem explora. Porém, qual saída da crise advirá, ante as bifurcações da história e a irreconciliável afirmação de interesses antagônicos de tais sujeitos, resta incógnita e só poderá ser resolvida politicamente.

Enquanto isso, contemos com juízes e juízas, sempre sem desatentar aos historiadores e historiadoras do Brasil.

\section{REFERÊNCIAS}

ANDRIEUX, François. "Le meunier de Sans-Souci, anedocte". In: ANDRIEUX, François. Contes et opuscules, em vers et em prose, suivis de poésies fugitives. Paris: Renouard, 1800, p. 45-48. Disponível em: https://gallica.bnf.fr/ark:/12148/bpt6k5488267h. Acessado em: 19.01.2019.

ARAÚJO JÚNIOR, Francisco Milton. "A terceirização e o descompasso com a higidez, saúde e segurança no meio ambiente laboral: responsabilidade solidária do tomador do serviço a partir das normas de saúde e

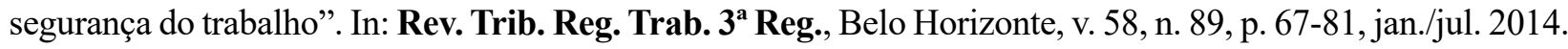

BARBAGELATA, Héctor-Hugo. O particularismo do Direito do Trabalho. Trad. Irany Ferrari. São Paulo: LTr, 1996.

BARROS, Alice Monteiro de. Curso de Direito do Trabalho, 11. ed. São Paulo: LTr, 2017.

BARROS, Sérgio Resende de. Contribuição dialética para o constitucionalismo. Campinas: Millenium, 2008.

BENJAMIN, Walter. "Sobre o conceito da história". In: Obras escolhidas I: Magia e técnica, arte e política. Trad. Sérgio Paulo Rouanet, São Paulo: Brasiliense, 1994.

BENSAÏD, Daniel. Marx, o intempestivo: grandezas e misérias de uma aventura crítica (séculos XIX e XX). Trad. Luis Cavalcanti de M. Guerra. Rio de Janeiro: Civilização Brasileira, 1999a.

BENSAIID, Daniel. Os irredutíveis: teoremas da resistência para o tempo presente. Trad. Wanda Caldeira Brant. São Paulo: Boitempo, 2008.

BENSAÏD, Daniel. Qui-est le juge? Pour en finir avec le Tribunal de l'Histoire. Paris: Fayard, 1999b.

BEZERRA LEITE, Carlos Henrique. Curso de Direito do Trabalho: Teoria geral e direito individual do trabalho. 3. ed., Curitiba: Juruá, 2008.

BIAVASCHI, Magda Barros, "Direito e Justiça do Trabalho no Brasil: notas sobre uma trajetória com bem mais de 70 anos". In: Revista do Tribunal Superior do Trabalho, Brasília, v. 77, n. 2, abr/jun 2011.

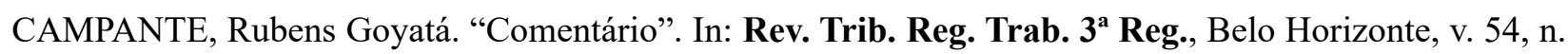
84, jul./dez.2011.

DALAZEN, João Oreste. "Discurso do presidente do TST, Ministro João Oreste Dalazen, em homenagem aos 70 anos da Justiça do Trabalho". In: Revista do Tribunal Superior do Trabalho, Brasília, v. 77, n. 2, abr/jun 2011.

EDELMAN, Bernard. A legalização da classe operária. Trad. Marcus Orione (coord.) et al. São Paulo: Boitempo, 2016.

ESTADÃO. "Contribuição sindical é herança fascista, diz relator da reforma trabalhista". Publicado em 17.04.2017. Disponível em: https://economia.estadao.com.br/noticias/geral,contribuicao-sindical-e-heranca-fascista-diz-relator-da-reforma-trabalhista,70001741336. Acessado em: 17.04.2019.

EXAME. "Férias, transporte e home office: o que pode mudar na CLT. Publicado em 12.04.2017. Disponível em:https://exame.abril.com.br/economia/ferias-transporte-e-home-office-o-que-pode-mudar-na-clt/. Acessado em: 17.04.2019. 
Sobre os usos da miséria historiográfica e a relevância da investigação história na aplicação do direito do trabalho SEFERIAN, G.

FAYET JÚNIOR, Ney. FRAGA, Ricardo Carvalho."Um dia na vida de um trabalhador; verdade e consequências jurídicas do processo produtivo no contexto da sociedade de risco". In: Rev. Trib. Reg. Trab. $3^{\mathbf{a}}$ Reg., Belo Horizonte, v. 54, n. 84, p. 289-305, jul./dez.2011.

GIGLIO, Wagner D., "Setenta anos de evolução da Justiça do Trabalho". In: Revista do Tribunal Superior do Trabalho, v. 77, n. 2, abr/jun 2011.

GOMES, Angela de Castro. A invenção do trabalhismo. 3 ed., Rio de Janeiro: FGV, 2005.

GRESPAN, Jorge. O Negativo do Capital. São Paulo: Expressão Popular, 2012.

JEAMMAUD, Antoine et al. Le Droit capitalista du travail. Grenoble: PUG, 1980.

LEFEBVRE, Henri. Introdução à modernidade: prelúdios. Rio de Janeiro: Paz e Terra, 1969.

LOPES, Mônica Sette. "Direito e crônicas: a encantadora alma das ruas". In: Rev. Trib. Reg. Trab. $\mathbf{3}^{\mathbf{a}}$ Reg., Belo Horizonte, v. 45, n. 75, jan./jun.2007.

LÖWY, Michael."Crise ecológica, crise capitalista, crise de civilização: a alternativa ecossocialista". Caderno CRH, Salvador, v. 26, 67, p. 79-86, Jan./Abr.2013.

LÖWY, Michael. Paysages de la vérité: introduction a une sociologie critique de la connaissance. Paris: Anthropos, 1985.

LÖWY, Michael. A política do desenvolvimento desigual e combinado: a teoria da revolução permanente. Trad. Luis Gustavo Soares. São Paulo: Sundermann, 2015.

LÖWY, Michael. Walter Benjamin: aviso de incêndio: uma leitura das "Teses sobre o conceito de História”. São Paulo: Boitempo, 2005.

LUKÁCS, Georg. História e Consciência de Classe: estudos sobre a dialética marxista. Trad. Rodnei Nascimento, Rev. Karina Janini. São Paulo: Martins Fontes, 2003.

MANDEL, Ernest. From class society to communism: an introduction to marxism. Trad. Louisa Sadler. Londres: Ink Link, 1977.

MARX, Karl. Crítica da Filosofia do Direito de Hegel. Trad. Rubens Enderle e Leonardo de Deus. São Paulo: Boitempo, 2005.

MARX, Karl. ENGELS, Friedrich. A ideologia alemã. Trad. Luciano Cavini Martorano, Nélio Schneider e Rubens Enderle. São Paulo: Boitempo, 2007.

ENGELS, Friedrich. Manifesto Comunista. Trad. Álvaro Pina. São Paulo: Boitempo, 2010.

MELLO, Marco Aurélio Mendes de Farias. "Justiça do Trabalho: 70 anos", in Revista do Tribunal Superior do Trabalho, Brasília, v. 77, n. 2, abr/jun, 2011.

MERÇON, Paulo Gustavo de Amarante. "Direito do trabalho novo". In: Rev. Trib. Reg. Trab. 3a Reg., Belo Horizonte, v. 51, n. 81, p. 137-154, jan./jun.2010.

MORAES FILHO, Evaristo de. Introdução ao Direito do Trabalho. $2^{\mathrm{a}}$.ed. São Paulo: LTr, 1978.

NASCIMENTO, Amauri Mascaro. Conflitos coletivos de trabalho: fundamentos do sistema jurisdicional brasileiro. São Paulo: Saraiva, 1978.

OLIVEIRA, Murilo C.S. “A ressignificação da dependência econômica”.In: Rev. Trib. Reg. Trab. $3^{\mathbf{a}}$ Reg., Belo Horizonte, v. 54, n. 84, p. 55-77, jul./dez.2011.

O GLOBO. "Frase a frase, a receita do ministro Paulo Guedes para a economia do país". Publicado em 02.01.2019. Disponível em: https://oglobo.globo.com/economia/frase-frase-receita-do-ministro-paulo-guedes-para-economia-do-pais-23341764. Acessado em: 05.01.2019.

PACHUKANIS, Evgeni. A teoria geral do direito e o marxismo e ensaios escolhidos (1921-1929). Trad. Lucas Simone. São Paulo: Sundermann, 2017.

RAMOS FILHO, Wilson. "Crise capitalista, duração do trabalho e gestão empresarial”. In: Direitos funda- 
Sobre os usos da miséria historiográfica e a relevância da investigação história na aplicação do direito do trabalho SEFERIAN, G.

mentais e justiça, n. 6, Porto Alegre: PUC-RS, 2009

RAMOS FILHO, Wilson. Direito Capitalista do Trabalho. São Paulo: LTr, 2012.

REZENDE, Roberto Vieira de Almeida. "A igualdade de direitos entre trabalhador portuário avulso e trabalhador com vínculo permanente”, in: Revista do TRT da $2^{a}$ Região, São Paulo, n. 1/2009, p. 85-168.

RIBEIRO, Fábio Túlio Correia. "Quem é o homem-trabalhador, esse sujeito detentor de direitos sociais de que fala a Constituição, e o que significa dizer que ele tem dignidade?". In: Revista do Tribunal Superior do Trabalho, v. 77, n. 3, jul/set 2011.

ROMITA, Arion Sayão. O fascismo no Direito do Trabalho brasileiro: influência da Carta del Lavoro sobre a legislação trabalhista brasileira.São Paulo: LTr, 2001.

ROMITA, Arion Sayão. A matriz ideológica da CLT. Disponível em: http://www.andt.org.br/f/A MATRIZ_IDEOLOGICA_DA_CLT\%5B1\%5D.pdf. Acessado em: 12.12.2018.

SCHIAVI, Mauro "Comentários às recentes alterações das súmulas e Ojs do Tribunal Superior do Trabalho". In: Revista do TRT da $2^{a}$ Região, São Paulo, n. 4/2010, p. 359-366.

SEFERIAN Scheffer Machado, Gustavo. "Um dedo contendo o dilúvio: alguns apontamentos sobre a Revolução Russa e a criação da OIT". In: BATISTA, Flávio Roberto. SEFERIAN Scheffer Machado, Gustavo. Revolução Russa, Estado e Direito. São Paulo: Dobradura, 2017.

SEGADAS VIANA, José de. "Antecedentes históricos". In: SÜSSEKIND, Arnaldo Lopes. MARANHÃO, Délio. SEGADAS VIANA, José de. Instituições de Direito do Trabalho. 13a. Ed, São Paulo: LTr, 1993.

SILVA, Homero Batista Mateus da. Curso de direito do trabalho aplicado: volume I, parte geral. $3^{\text {a }}$ ed. São Paulo: Revista dos Tribunais, 2015.

SOUBHIA, Samir. "A aplicação subsidiária do direito comum na execução trabalhista”. In: Revista do TRT da $2^{\text {a }}$ Região, São Paulo, n. 6/2010, p. 93-100.

SOUTO MAIOR, Jorge Luiz. Curso de Direito do Trabalho: Teoria Geral do Direito do Trabalho, vol. I., parte I, São Paulo: LTr, 2012.

SOUTO MAIOR, Jorge Luiz. "O 'fascismo' como retórica e a democracia em risco". Publicado em 03.01.2019. Disponível em: https://www.jorgesoutomaior.com/blog/o-fascismo-como-retorica-e-a-democracia-em-risco. Acessado em: 17.04.2019.

SOUTO MAIOR, Jorge Luiz. História do Direito do Trabalho no Brasil: curso de direito do trabalho, Vol. I, parte II. São Paulo: LTr, 2017.

TST. "Ministro Horácio Senna Pires se aposenta com quatro décadas de magistratura". Publicado em 28.05.2012. Disponível em: http://www.tst.jus.br/noticias/-/asset_publisher/89Dk/content/id/1752051. Acessado em: 19.01.2019.

TROTSKY, Leon. "Balanço e perspectivas". In: A teoria da revolução permanente. São Paulo: Sundermann, 2011.

TROTSKY, Leon. História da Revolução Russa. T. I, Trad. Diego de Siqueira. São Paulo: Sundermann, 2007.

VIANA, Márcio Túlio. DELGADO, Gabriela Neves. AMORIM, Helder Santos. "Terceirização - aspectos gerais. A última decisão do STF e a Súmula 331 do TST. Novos enfoques". In: Revista do Tribunal Superior do Trabalho, v. 77, n. 1, Brasília: TST, jan/mar 2011.

VIANNA, Luiz Werneck. Liberalismo e Sindicato no Brasil. 3a. ed. Rio de Janeiro: Paz e Terra, 1989.

VITORINO, Artur José Renda. "Escravismo, proletários e a greve dos compositores tipográficos de 1858 no Rio de Janeiro". In: Cadernos AEL, v. 6, n.10/11, 1999, p. 71-108. 
Data de submissão do artigo: Abril de 2019

Data de aceite do artigo: Março de 2020(*)

\section{(*) NOTA TÉCNICA:}

Esclarecemos que, em razão do ataque de hackers a que foi submetido o conjunto de periódicos da Universidade Federal de Goiás (UFG), ao que se inclui a Revista da Faculdade de Direito da UFG (RFD/UFG), os artigos ordenados entre os números 21-30, referentes ao volume 43, embora tenham sido recebidos e aceitos em datas distintas e anteriores, dado o perecimento de suas referências, foram todos registrados com o expediente de aceite no mês de março de 2020. 